\title{
Factors Influencing the Natural Forest Regeneration at Khadimnagar National Park, Bangladesh
}

\author{
MAHEDI HASAN LIMON*, SAIDA HOSSAIN ARA \& MOHAMMAD GOLAM KIBRIA \\ Department of Forestry and Environmental Science, Shahjalal University of Science and Technology, \\ Sylhet-3114, Bangladesh \\ *Corresponding author: limonsust13@gmail.com \\ Received: 18 May $2021 \quad$ Accepted: 16 June 2021 \\ Published: 30 June 2021
}

\begin{abstract}
Natural regeneration is an indicator of a healthy forest, hence, understanding the influence of site factors on natural regeneration is a significant concern for ecologists. This work aimed to assess the impact of site factors on natural tree regeneration at Khadimnagar National Park (KNP). Biotic factors (tree density, tree species richness, and basal area), physical factors (elevation, canopy openness), and soil properties (bulk density, moisture content, soil pH, organic matter, sand, silt, and clay) data were investigated from 71 sample plots to examine their effects on natural regeneration density and richness in KNP. Stepwise multiple linear regression analysis was done to predict both regeneration density and regeneration richness. The results showed that soil $\mathrm{pH}(\mathrm{p}<0.001)$, canopy openness $(\mathrm{p}<0.001)$, tree species richness $(\mathrm{p}<0.01)$, and bulk density $(\mathrm{p}<0.01)$ had a significant effect on regeneration density, explaining $42 \%$ of the total variation. Regeneration richness was driven by four factors: tree species richness ( $\mathrm{p}<0.01)$, soil $\mathrm{pH}(\mathrm{p}<0.001)$, elevation $(\mathrm{p}<0.01)$, and canopy openness $(\mathrm{p}<0.01)$ with a model that explained $60 \%$ of the total variation. This study observed that soil $\mathrm{pH}$, tree species richness, and canopy openness are the main controlling factors that influenced both the density and richness of regenerating species in KNP. Therefore, these findings have implications for natural resource management, especially in selecting suitable silvicultural systems in a tropical forest under protected area management where enhanced tree cover and conservation of biodiversity are needed.
\end{abstract}

Keywords: Abiotic factors, biotic factors, Khadimnagar National Park, regeneration density and richness

Copyright :This is an open access article distributed under the terms of the CC-BY-NC-SA (Creative Commons Attribution-NonCommercial-ShareAlike 4.0 International License) which permits unrestricted use, distribution, and reproduction in any medium, for non-commercial purposes, provided the original work of the author(s) is properly cited.

\section{INTRODUCTION}

Tropical forests provide a wide range of ecosystem services due to their high diversity, which allows them to pack in more species and biomass than other forests (Brandon, 2014). Tropical forests provide a variety of benefits to their surrounding communities including timber (Uddin et al., 2013), non-timber products, clean air, safe water, biodiversity, carbon sequestration, and storage (Donato et al., 2011; Lee et al., 2014) as well as recreational and spiritual services (MEA, 2005; UNEP, 2014). Tropical forests once covered around $12 \%$ of the Earth's land surface, but now only make up around 5\% (600 million ha.) of the earth's terrestrial surface or approximately $28 \%$ of land in the tropics (Corlett \& Primack, 2011; Hansen et al., 2013; Brandon, 2014). Throughout human history, the worldwide area of naturally regenerating forests has decreased, halving in the last three centuries. Forests have effectively vanished in 25 countries, with another 29 countries losing more than $90 \%$ of their historical forest cover (MEA, 2005).

To conserve and maintain biodiversity, the natural regeneration of the plant species plays a crucial role in a forest (Hossain et al., 2004). The nature of the forest community depends upon the ecological character such as sites, species diversity, and regeneration status of species (Choudhury et al., 2014). The long-term sustainability of a forest can be triggered by successful regeneration potential (Malik \& Bhatt, 2016). Several biotic (i.e. floristic composition, seed production, competition, predation etc.) and abiotic factors (i.e. soil, water, light, topography etc.) within a given climatic region often influence natural regeneration success in a forest (Tinya et al., 2019). Knowledge regarding plant regeneration status can help in 
developing management options and as well as priority setting (Zegeye et al., 2011). It is essential to maintain forest renewal through natural and artificial regeneration depending on the management objectives (Rahman et al., 2011).

The vegetation of Bangladesh (with 7000 plant species) is a part of the Indo-Myanmar region, which is one of the ten global biodiversity hot spot areas (Hossen \& Hossain, 2018), and it is speciesrich because of its unique geophysical location (Hossain, 2001). Presently, Bangladesh has 2.6 million ha of forest cover that comprises about $17 \%$ of the country's total land area (Reza \& Hasan, 2019). Several factors such as population pressure, inappropriate and poor management practices are causing severe stress on the country's natural forest (Haider et al., 2017). According to Rahman et al. (2000), a continuous decrease in native species was also accelerating at an alarming rate, causing rapid loss and forest degradation in Bangladesh. Bangladesh lost 2600 hectares of primary forest per year (at an annual deforestation rate of 0.2 percent) between 1990 and 2015. From 1.494 million hectares in 1990 to 1.429 million hectares in 2015, primary forest acreage has gradually reduced (FAO, 2015). Therefore, the natural regeneration of forest tree species needs to be enhanced by using suitable artificial and natural regeneration processes to conserve forest flora and maintain sustainable yield, goods, and services (Haider et al., 2017).
Several studies were conducted at Khadimnagar National Park (KNP) focusing on assessing the natural regeneration status, diversity, and distributional pattern of different tree species (Rahman et al., 2011; Sobuj \& Rahman, 2011), tree species distribution along with soil variables (Ara et al., 2021) and forest cover change (Redowan et al., 2014). However, our study was first to investigate the factors influencing the natural tree regeneration at Khadimnagar National Park (KNP). We asked a specific question, which site factors influence the natural tree regeneration density and richness in KNP? We hypothesise that multiple biotic and abiotic factors in combination, rather a single factor, influence the natural tree regeneration of KNP.

\section{MATERIALS AND METHODS}

\section{Study Area}

The study was carried out at KNP $\left(24^{\circ} 56^{\prime}-24^{\circ} 58^{\prime}\right.$ $\mathrm{N}$ and $91^{\circ} 55^{\prime}-91^{\circ} 59$ 'E), located in the Khadimnagar Union of Sylhet Sadar Upazila in the district of Sylhet, Bangladesh (Figure 1). The total area of the park is around 679 ha and was declared as a national park in 2006 (Sobuj \& Rahman, 2011). KNP undulates with slopes and hillocks, locally known as "tilla" which usually ranges between $10-50 \mathrm{~m}$ in height (Redowan et al., 2014).

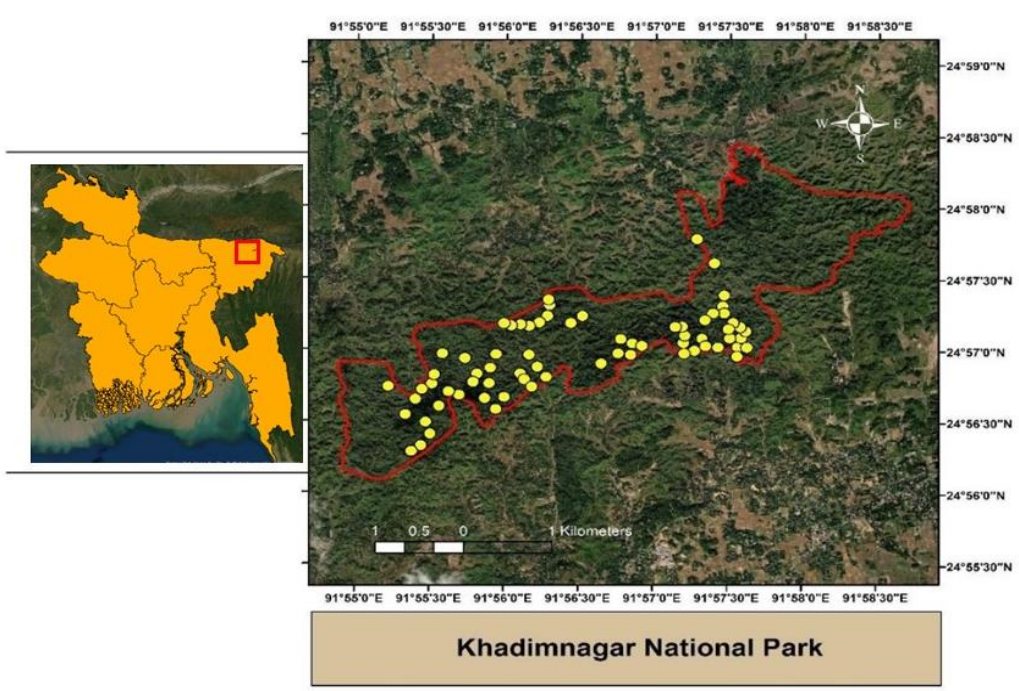

Figure 1. Location of the study area (Khadimnagar National Park, Bangladesh). The yellow circle representing studied sample plots (Shapefile Source: www.protectedplanet.net) 
The natural characteristics of the climate in these areas are much warmer and humid. The tropical climate is in general subjected to heavy rainfall. During December, the temperature increases, and in January, it is much cooler. These areas have a maximum average temperature of 30.7 ${ }^{\circ} \mathrm{C}$ with an average minimum temperature of 18.9 ${ }^{\circ} \mathrm{C}$ (Rahman et al., 2011). KNP is located in a region that is prone to heavy rainfall. The total average annual rainfall is $3931 \mathrm{~mm}$ and most of which falls between June and September (Rahman et al., 2011). The topsoil of the Khadimnagar Hills is generally hard and clayey. The soil texture of the $\mathrm{KNP}$ is usually clay loam which is acidic in nature (Ara et al., 2021). The common growing tree species in KNP are Dipterocarpus turbinatus (Garjan), Artocarpus chapalasha (Chapalish), Chukrasia tabularis (Chickrasi), Aquilaria sinensis (Agar), Toona ciliate (Toon), Tectona grandis (Teak), Syzigium cumini (jam), Senna siamia (Minjiri), Mangifera indica (Aam) and different bamboo species.

\section{Study Variables}

We considered different biotic factors (tree density, tree species richness, and basal area), physical factors (elevation and canopy openness), and soil properties $(\mathrm{pH}$, bulk density, moisture content, organic matter, sand, silt, and clay) as explanatory variables, while regeneration density \& richness as the response variables for the study (Table 1).

Table 1. List of variables considered in the study

\begin{tabular}{ll}
\hline Variables & \\
\hline Response & $\begin{array}{l}\text { Regeneration Density }\left(\mathrm{ha}^{-1}\right) \\
\text { Regeneration Richness }\left(\mathrm{plot}^{-1}\right)\end{array}$ \\
& Tree Density $\left(\mathrm{ha}^{-1}\right)$ \\
Biotic & Tree Species Richness $\left(\mathrm{plot}^{-1}\right)$ \\
factor & Basal Area $\left(\mathrm{m}^{2} \mathrm{ha}^{-1}\right)$ \\
Physical & Elevation $(\mathrm{m})$ \\
Factor & Canopy Openness $(\%)$ \\
& Soil pH \\
& Soil BD $\left(\mathrm{gcm}{ }^{-3}\right)$ \\
Soil & Soil MC $(\%)$ \\
Properties & Soil OM $(\%)$ \\
& Sand (\%) \\
& Silt $(\%)$ \\
& Clay $(\%)$ \\
\hline
\end{tabular}

Notes: MC: Moisture Content; BD: Bulk Density; OM: Organic Matter

\section{Vegetation Survey}

Field data were collected during November and December of 2018. A total number of 71 plots with a size of $(15 \mathrm{~m} \times 15 \mathrm{~m})$ were established throughout the forest randomly to collect different vegetation data. Sufficient efforts were made to distribute the plots throughout the whole forest to cover a wide range of forest areas (Figure 1). All the trees greater than or equal to $5 \mathrm{~cm}$ diameter at breast height $(\mathrm{dbh})(1.30 \mathrm{~m}$ height above the ground level) (Pearson et al., 2007) were recorded on each plot and their dbh were measured using a diameter tape. For multi-stem tree species with forking below breast height, we measured the diameters of all stems independently. Hagaaltimeter was used to measure the tree height of the studied forest. To ensure optimal monitoring and recording of all tree species regeneration, five subplots $(2 \mathrm{~m} \times 2 \mathrm{~m})$ within these plots were taken: four at every corner of the plot and one in the center of the plot. All the tree regeneration (less than $5 \mathrm{~cm}$ $\mathrm{dbh}$ and greater than or equal to $20 \mathrm{~cm}$ in height) were considered as regenerating seedlings, thereafter, counted from the sub-plots. Tree species were identified with the help of an experienced local guide. The species, which were not possible to identify in the field, photographs were taken, and samples of those unidentified species were collected and identified with the help of taxonomic textbooks (e.g., Hossain, 2015) and web-based data. Regeneration density was calculated as the total number of individuals of a tree species per plot then it was converted into density per hectare. Regeneration richness was calculated by counting the total number of tree species present in the regeneration stage within the plot. Both regeneration density and richness per plot were considered as response variables. Tree density was also calculated as the total number of individuals of a species per plot. Then the tree density of the plot was converted into density per hectare. At the same time, tree richness was calculated by counting the total number of different species present within the sample plot.

The canopy openness of the studied plot was measured by using the Spherical Crown Densiometer. The basal area per plot was calculated by using the following Eq. (1):

$$
\text { Basal area per tree }=3.14 \times\left(\frac{D^{2}}{4}\right)
$$

Where, $\mathrm{D}=$ Diameter at breast height in (m) 
The basal area per plot was then converted to the basal area per hectare. Each plot's geographic location and elevation were taken at the center of the plot using a hand-held Global Positioning System (GPS, 12 Channel, Garmin International Inc, USA).

\section{Similarity Index}

The Sorensen similarity (K) coefficient was used to calculate similarities of species between the plotlevel tree and tree regeneration samples based on the presence or absence of certain species (Ifo $e t$ al., 2016) following the Eq. (2).

$$
\mathrm{K}(\%)=\frac{(2 a \times 100)}{(2 a+b+c)}
$$

Where $\mathrm{a}=$ number of common presences for both floristic samples, $b=$ number of unique presences in the first floristic sample, $\mathrm{c}=$ number of unique presences in the second floristic sample.

\section{Soil Sampling and Analysis}

Soil $\mathrm{pH}$, moisture content, bulk density, organic matter, soil texture (sand, silt, and clay) were considered for this study. Five soil samples, four from each corner and the center of the plot, were taken. Each of the samples was taken at $10 \mathrm{~cm}$ depth using soil cores. A solid ring or volumetric cylinder was pressed into the soil to take a core sample. The samples from each plot were then mixed all-together to form one composite sample prior to analysis. All the coarse materials like stones, branches, undecomposed materials, roots were removed by passing through a sieve $(2 \mathrm{~mm})$. The analysis of soil was conducted in the Soil Laboratory of Forestry and Environmental Science, Shahjalal University of Science and Technology. Soil $\mathrm{pH}$ and moisture content were measured with Kelway Soil Tester and a digital moisture meter (FSI, New Jersey, USA), respectively. Soil bulk density $\left(\mathrm{g} / \mathrm{cm}^{3}\right)$ was calculated by using the oven-dry method at $105^{\circ} \mathrm{C}$ (Blake \& Hartge, 1986). The loss ignition method was used to measure organic matter and the standard Hydrometer method was used to calculate soil texture (sand, silt, and clay).

\section{Data Analysis}

Descriptive statistics were performed to describe the basic features of all variables considered. To investigate the relationship between regeneration patterns and different biotic and abiotic factors, stepwise multiple linear regression analyses were done and excluded the model's non-significant factors. The Kolmogorov-Smirnov test was used to check the normality of the residuals before doing the analysis. All the analyses were performed by using SPSS version 21.0.

\section{RESULTS}

\section{Regeneration Patterns and Other Stand Characteristics of KNP}

A total number of 19 regenerating species and 22 tree species were recorded (Table 2). Regeneration density ranged from 0 to 7500 individuals per hectare with a mean density of 3140 individuals per hectare.

Average regeneration richness was 1.9 per plot. The number of trees per hectare ranged between 178 and 889 across the plots. The mean density was 421.9 individuals per hectare, and the mean tree species richness was 2.04 per plot. The mean basal area per hectare was $28.49 \mathrm{~m}^{2}$. The elevation ranged from $28 \mathrm{~m}$ to $51 \mathrm{~m}$ above sea level in the studied plots. Mean canopy openness was 16.9\%. The mean soil moisture content was $24.82 \%$, whereas the mean bulk density and mean soil $\mathrm{pH}$ were $1.17 \mathrm{~g} / \mathrm{cm}^{3}$ and 5.23 , respectively. Mean soil organic matter was $18.27 \%$, and the mean sand, silt, and clay were $93.28 \%, 5.42 \%$, and $1.29 \%$, respectively (Table 3 ). The value of the calculated coefficient of similarity for the Sorenson index was $48.10 \%$.

\section{Influence of Site Factors on Regeneration Density}

Stepwise multiple regression analysis revealed that four variables (such as $\mathrm{pH}$, canopy openness, bulk density, and tree species richness) significantly affected the regeneration density (Figure 2) out of twelve explanatory variables (Table 1). The regression model explained $42 \%$ variations in total. Soil $\mathrm{pH}$ (standardized coefficient, $\beta=0.389$, $\mathrm{p}<0.001$ ) positively affected regeneration density. However, canopy openness $(\beta=-0.442, p<0.001)$, bulk density $(\beta=-0.299, p<0.01)$ and tree species richness $(\beta=-0.299, p<0.01)$ had negative effect on regeneration density (Table 4). No significant influences were found for tree density, basal area, elevation, soil moisture content, soil organic matter, sand, silt, and clay. 
Table 2. List of tree species and regenerating species recorded from Khadimnagar National Park

\begin{tabular}{|c|c|c|c|c|}
\hline Family & Scientific Name & Nativity & Usage & Source(s) \\
\hline Anacardiaceae & Mangifera indica $^{*}$ & Native & $\mathrm{Fd}, \mathrm{Fo}, \mathrm{M}, \mathrm{T}$ & 1 \\
\hline \multirow[t]{2}{*}{ Combretaceae } & Terminalia arjuna* & Native & $\mathrm{Fd}, \mathrm{M}, \mathrm{N}, \mathrm{T}$ & $1,2,3$ \\
\hline & Terminalia catappa* & Exotic & $\mathrm{Fd}, \mathrm{Fo}, \mathrm{M}, \mathrm{N}$ & 1,2 \\
\hline \multirow[t]{2}{*}{ Dipterocarpaceae } & Dipterocarpus turbinatus ${ }^{*}$ & Native & $\mathrm{Fu}, \mathrm{M}, \mathrm{N}, \mathrm{T}$ & 1,3 \\
\hline & Acacia auricuiformis ${ }^{*}$ & Exotic & $\mathrm{Fu}, \mathrm{N}, \mathrm{T}$ & $1,2,4$ \\
\hline \multirow[t]{3}{*}{ Fabaceae } & Xylia xylocarpa* & Exotic & $\mathrm{M}, \mathrm{N}, \mathrm{T}$ & $\begin{array}{l}1,2,3, \\
4\end{array}$ \\
\hline & Acacia mangium ${ }^{*}$ & Exotic & $\mathrm{Fd}, \mathrm{Fu}, \mathrm{T}, \mathrm{N}$ & $1,2,4$ \\
\hline & Senna siamea* & Native & Fo, Fu, N, T & 1 \\
\hline Lamiaceae & Tectona grandis ${ }^{*}$ & Exotic & $\mathrm{M}, \mathrm{T}$ & $1,2,4$ \\
\hline Lythraceae & Lagerstroemia speciosa* & Native & $\mathrm{O}, \mathrm{T}$ & 1 \\
\hline \multirow[t]{2}{*}{ Magnoliaceae } & Magnolia champaca* & Native & $\mathrm{N}, \mathrm{T}$ & 1 \\
\hline & Chukrasia tabularis ${ }^{*}$ & Native & $\mathrm{N}, \mathrm{T}$ & 1,2 \\
\hline \multirow[t]{3}{*}{ Meliaceae } & Toona ciliate $^{*}$ & Native & $\mathrm{M}, \mathrm{N}, \mathrm{T}$ & 1,3 \\
\hline & Ficus benghalensis & Native & $\mathrm{Fd}, \mathrm{Fo}, \mathrm{M}, \mathrm{N}$ & 2,3 \\
\hline & Ficus racemose ${ }^{*}$ & Native & $\mathrm{Fd}, \mathrm{Fo}, \mathrm{M}, \mathrm{N}$ & 2,3 \\
\hline \multirow[t]{3}{*}{ Moraceae } & Artocarpus chaplasha* & Native & $\mathrm{Fd}, \mathrm{Fo}, \mathrm{T}$ & $1,2,3$ \\
\hline & Artocarpus heterophyllus* & Native & $\mathrm{Fd}, \mathrm{Fo}, \mathrm{N}, \mathrm{T}$ & 1,3 \\
\hline & Streblus asper* & Exotic & $\mathrm{M}$ & 5 \\
\hline Myrtaceae & Syzygium cumini ${ }^{*}$ & Native & $\begin{array}{l}\mathrm{Fd}, \mathrm{Fo}, \mathrm{Fu}, \mathrm{N}, \\
\mathrm{T}\end{array}$ & $1,2,3$ \\
\hline Phyllanthaceae & Baccaurca ramiflora* & Native & Fo, M & 6 \\
\hline Santalaceae & Santalum album & Exotic & $\mathrm{M}, \mathrm{T}$ & 2 \\
\hline Thymelaceae & Aquilaria sinensis & Exotic & $\mathrm{N}$ & 2,3 \\
\hline
\end{tabular}

Table 3. Descriptive statistics of different variables at Khadimnagar National Park

\begin{tabular}{lcllll}
\hline Stand characteristics & $\begin{array}{c}\text { Plot no. } \\
(\mathrm{N})\end{array}$ & Mean & $\begin{array}{c}\text { Std. } \\
\text { Error }( \pm)\end{array}$ & Max. & Min. \\
\hline Regeneration density $\left(\mathrm{ha}^{-1}\right)$ & 71 & 3140.8 & 185.59 & 7500 & 0 \\
Regeneration species richness $\left(\mathrm{plot}^{-1}\right)$ & 71 & 1.9 & 0.1 & 4 & 0 \\
Tree density $\left(\mathrm{ha}^{-1}\right)$ & 71 & 421.9 & 18.2 & 888.88 & 177.77 \\
Tree species richness $\left(\mathrm{plot}^{-1}\right)$ & 71 & 2.04 & 0.11 & 5 & 1 \\
Basal area $\left(\mathrm{m}^{2} \mathrm{ha}^{-1}\right)$ & 71 & 28.49 & 1.79 & 64.25 & 2.62 \\
Elevation $(\mathrm{m})$ & 71 & 40.37 & 0.67 & 51 & 28 \\
Canopy openness $(\%)$ & 71 & 16.9 & 0.76 & 36.25 & 7.18 \\
Soil MC $(\%)$ & 71 & 24.82 & 0.4 & 16.53 & 5.8 \\
Soil BD $\left(\mathrm{gcm}^{-3}\right)$ & 71 & 1.17 & 0.01 & 1.52 & 0.93 \\
Soil pH & 71 & 5.23 & 0.04 & 5.8 & 4.5 \\
Soil OM $(\%)$ & 71 & 18.27 & 0.43 & 25.51 & 11.13 \\
Sand $(\%)$ & 71 & 93.28 & 0.2 & 96.7 & 88.6 \\
Silt $(\%)$ & 71 & 5.42 & 0.22 & 9.6 & 0.7 \\
Clay $(\%)$ & 71 & 1.29 & 0.09 & 3.1 & 0 \\
\hline
\end{tabular}

Notes: MC: Moisture Content; BD: Bulk Density; OM: Organic Matter 


\section{Influence of Site Factors on Regeneration Richness}

The stepwise regression model for regeneration richness identified four factors (i.e. tree species richness, $\mathrm{pH}$, elevation, and canopy openness) that significantly affected regeneration richness (Figure 3 ), and the model explained $60 \%$ of the total variation (Table 5). No other factor significantly affected the regeneration richness.

Whereas tree species richness $(\beta=0.280$, $\mathrm{p}<0.01)$ and soil $\mathrm{pH}(\beta=0.325, \mathrm{p}<0.001)$ positively affected regeneration richness, elevation $(\beta=$ $0.283, p<0.01)$ and canopy openness $(\beta=-0.235$, $\mathrm{p}<0.01)$ affected it negatively.

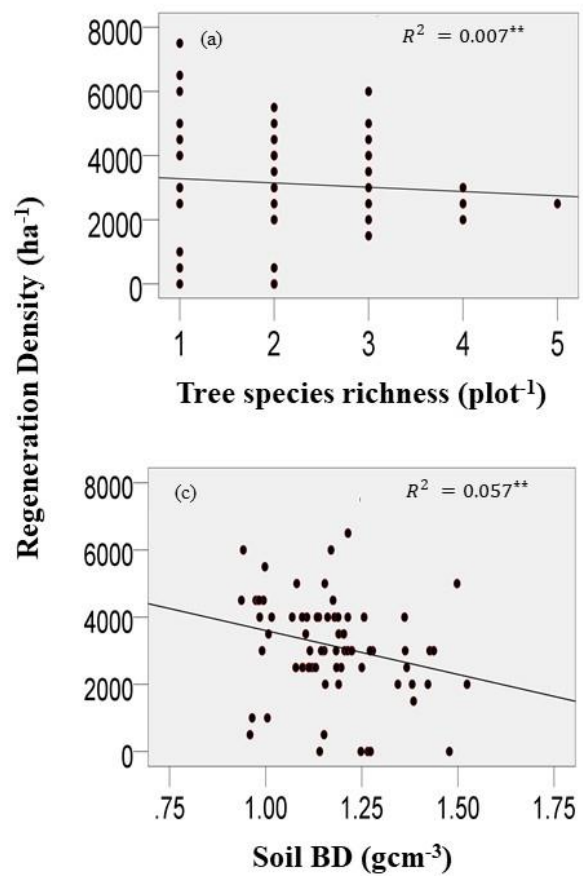

\section{DISCUSSION}

Natural regeneration assessment plays a vital role in sustainable forest management, as natural regeneration is key to the successful establishment of the mature forest community (Bose et al., 2016). Hence, we studied the influence of some selected site factors on the natural tree regeneration pattern (density and richness) in a tropical semi-evergreen forest of Bangladesh.

A total number of 19 regenerating species were found in the studied sample plots with a density of 3140 individuals per ha in KNP. Motaleb and Hossain (2007) reported 29 regenerating species in the Chittagong South Forest Division. Alamgir and
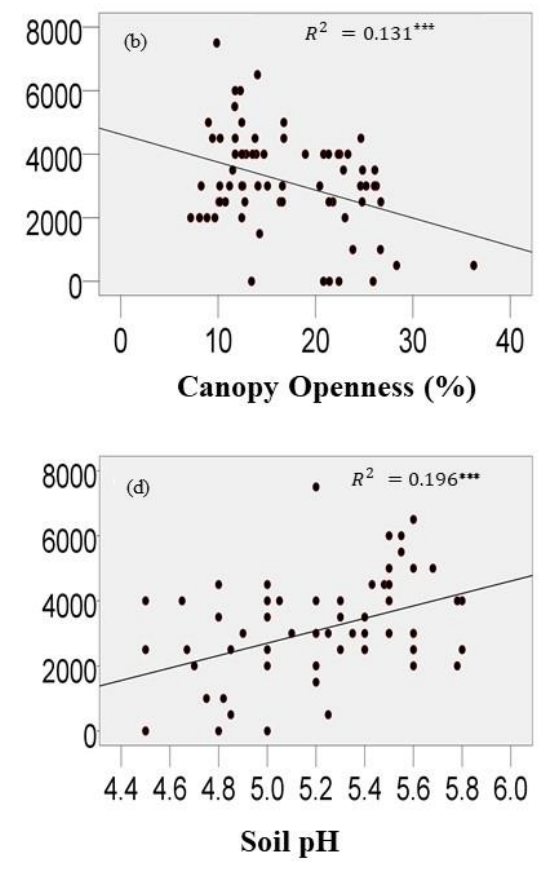

Figure 2. Bivariate relationship between regeneration density and different significant biotic and abiotic factors (a) Tree species richness; (b) Canopy openness; (c) Soil BD; and (d) Soil pH) represented in a clockwise manner at Khadimnagar National Park. Soil BD: Soil Bulk Density; Significance level- ${ }^{* *} \mathrm{p}<0.01,{ }^{* * *} \mathrm{p}<0.001$

Table 4. The stepwise regression model for the natural regeneration density at Khadimnagar National Park

\begin{tabular}{|c|c|c|c|c|c|}
\hline Model & Variables & $\begin{array}{c}\text { Standardized } \\
\text { Coefficients }(\beta)\end{array}$ & $\mathrm{R}^{2}$ & $\mathrm{~F}$ & $\mathrm{p}$ \\
\hline $\begin{array}{l}\text { Regeneration } \\
\text { Density }\end{array}$ & $\begin{array}{c}\text { Soil pH } \\
\text { Canopy Openness } \\
\text { Bulk Density } \\
\text { Tree Species Richness }\end{array}$ & $\begin{array}{r}0.389 \\
-0.442 \\
-0.299 \\
-0.299 \\
\end{array}$ & 0.428 & 12.35 & $\begin{array}{l}0.000 \\
0.000 \\
0.004 \\
0.005 \\
\end{array}$ \\
\hline
\end{tabular}

Excluded variables: Tree density, elevation, basal area, soil moisture content, soil organic matter, sand, silt, and clay. 
Table 5. The stepwise regression model for the natural regeneration richness at Khadimnagar National Park

\begin{tabular}{lccccc}
\hline Model & Variables & $\begin{array}{c}\text { Standardized } \\
\text { Coefficients }(\beta)\end{array}$ & $\mathrm{R}^{2}$ & $\mathrm{~F}$ & $\mathrm{p}$ \\
\hline Regeneration & Tree Species Richness & 0.280 & \multirow{2}{*}{0.608} & 25.59 & 0.003 \\
Richness & Soil pH & 0.325 & & & 0.000 \\
& Elevation & -0.283 & & 0.007 \\
\hline
\end{tabular}

Excluded variables: Tree density, basal area, soil moisture content, soil bulk density, soil organic matter, sand, silt, and clay.
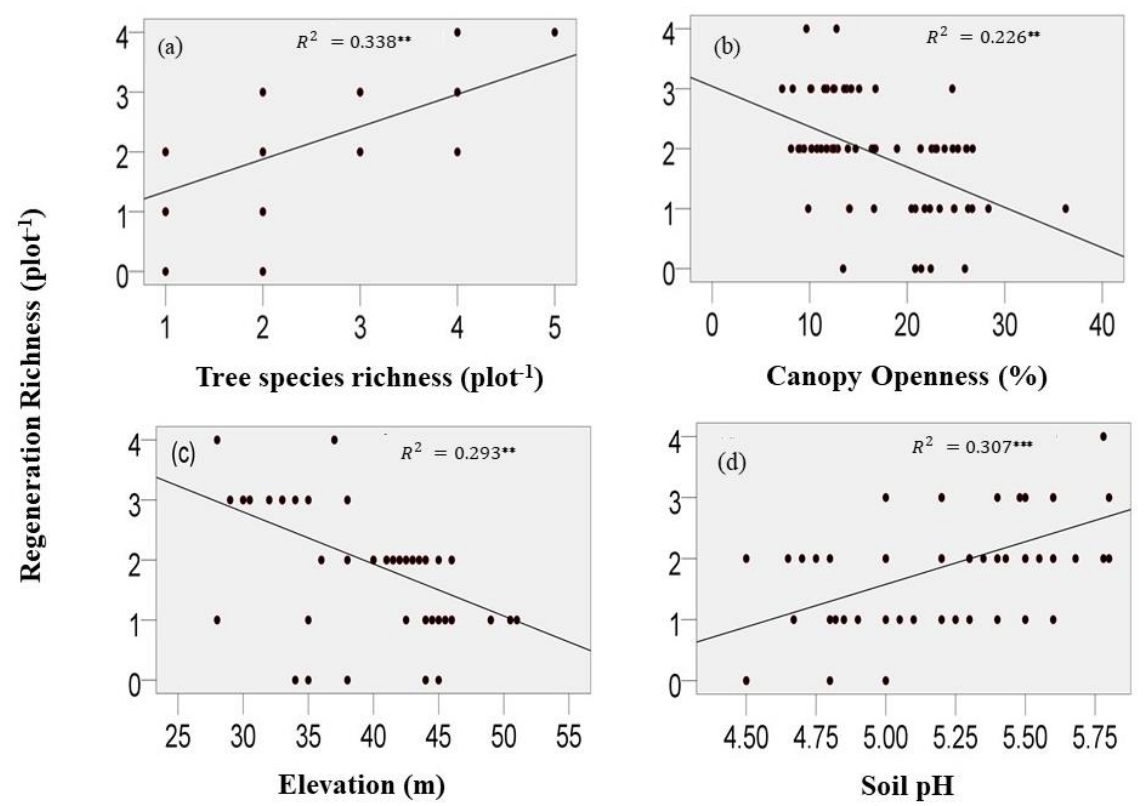

Figure 3. Bivariate relationship between regeneration richness and different significant biotic and abiotic factors (a) Tree species richness; (b) Canopy openness; (c) Elevation; and d. Soil pH) at Khadimnagar National Park Significance level- $* * \mathrm{p}<0.01, * * * \mathrm{p}<0.001$

Al-Amin (2007) documented 39 regenerating species in a proposed biodiversity conservation area in Chittagong, Bangladesh. Haider et al. (2017) found 70 regenerating species from Moulvibazar natural forest. Rahman et al. (2011) reported 55 regenerating species from KNP and Tilagor Eco-Park. However, it is inappropriate to compare the findings of this study with theirs as they have considered not only seedlings but also treelets that are $2 \mathrm{~cm} \leq \mathrm{dbh}$ and height $<10 \mathrm{~cm}$. Our study demonstrates a very low status of tree regeneration relative to other compared studies. Though one of the main objectives of the national park is to facilitate natural regeneration and thus to conserve and protect biodiversity, the studied forest is still far behind the satisfactory level. Despite prohibition, local inhabitants often enter the forest to collect fuelwoods and forest litters due to the lack of alternative cooking fuel. By doing so, they often damage seedlings of trees which may have led to the poorer condition of the regeneration status in the studied forest. Another serious threat to newly regenerated species is grazing and trampling by adjacent people's cattle. However, the natural regeneration in tropical forests is not controlled only by anthropogenic disturbances but also many biotic and abiotic factors ( Hartshorn, 1995; Chazdon, 2003).

The study results revealed that various site factors such as soil $\mathrm{pH}$, bulk density, tree species richness, and canopy openness significantly affect the regeneration density of KNP (Figure 2). While, species richness, soil $\mathrm{pH}$, elevation, and canopy openness were among the factors that control natural regeneration richness in the KNP (Figure $3)$. 


\section{Influence of Biotic Factors on Regeneration}

In this study, a positive trend was found between regeneration richness and tree richness. Khaine et al. (2018), observed a similar trend in a tropical forest of Myanmar. The resulted Sorensen similarity index $(48.01 \%)$ in this study also suggests that almost all the tree species were likely to reproduce regardless of their reproduction rate. It agrees with the expectation that regeneration richness would increase along with tree richness because tree species richness in a tree community ensures the availability of diverse propagules for the understory (Bose et al., 2016). Olson and Wagner (2011) also reported that overstory diversity significantly influences regeneration species richness positively. However, we found a negative relationship between tree species richness and regeneration density. The underlying cause of this association may be the competition for space and nutrients increases as the number of different tree species increases, which might ultimately affect the tree regeneration.

\section{Influence of Abiotic Factors on Regeneration}

In line with our expectation, regeneration density and regeneration richness increased along with soil $\mathrm{pH}$ which was slightly acidic and ranged between 4.5 and 5.8 in the study site. The $\mathrm{pH}$ range regulates the availability of soil nutrients for the plants. Soil $\mathrm{pH}$ oversees many plant-soil chemical relations, especially the cation/anion exchange capacities, the accessibility of micronutrients and toxic particles, because of its impact on solubility (Offord et al., 2014), thus influence the nutrient uptake by plants. It has been suggested that at low soil pH levels aluminium, iron, and manganese become available for plants to uptake, while in soil with high $\mathrm{pH}$ levels, calcium and potassium become abundant. However, soil pH lower than 4.5 and greater than 8.5 may make some of these nutrients inaccessible for plant uptake (Londo et al., 2006). According to Lončarić et al. (2008), most micronutrients become readily accessible to plant in slightly acid soils compared to neutral-alkaline soils that favour the plant. The effect of $\mathrm{pH}$ on the growth pattern of the plant through altering nutrients availability was also reported by Joshi and Ghosh (2003).

Soil bulk density significantly affected regeneration density negatively and contributed $10 \%$ when included in the regression model (Table 4). The underlying cause may be that high bulk density is an indicator of low soil porosity through soil compaction which, in turn, may restrict plant root growth by the inadequate movement of water and impaired air circulation (Arshad et al., 1997). Whereas low soil bulk density indicates the larger soil pores where roots can easily penetrate and absorb nutrients.

The elevation is an important physical factor affecting the composition, growth, and distribution of tropical forests (Enoki \& Abe, 2004). The negative relationship found between elevation and regeneration richness in KNP conforms to Rapoport's elevation rules, which state that with the increasing elevation, the richness of trees, mammals, grasshoppers, reptiles decrease (Bhattarai \& Vetaas, 2006). Although the elevation range in our study area is relatively low, it is most likely because of differential microhabitat (i.e. soil texture, availability of nutrients etc.) associated even with low elevational differences.

Canopy openness has a direct influence on regeneration growth and survival (Piiroinen et al., 2014) and indirectly influences regeneration by affecting the physical environment (Beckage \& Clark, 2003). Canopy openness decreased along with both the regeneration density and regeneration richness. The underlying cause may be due to the increased competition of regenerating tree species with ground vegetation in an open spot (Modrý et al., 2004). Nicotra et al. (1999) also observed a similar result in a study at a tropical forest of northeastern Costa Rica. Canopy openness and soil moisture content collectively regulate seed germination, seedling establishment, and seedling survival in tropical forests (Khurana \& Singh, 2001).

Finally, the present study was limited to a single data collection period. However, long-term monitoring of the variation in regeneration as well as other potentially limiting resources (i.e. light, water, nutrients availability) is needed to determine how spatial regeneration structure varies over time within the forest.

\section{CONCLUSION}

The study was performed to determine the influence of factors on natural regeneration patterns in Khadimnagar National Park. Findings revealed that bulk density affected tree regeneration density but not richness whereas, elevation did the opposite. Soil $\mathrm{pH}$, tree species richness, and canopy openness are the factors that 
influenced both the regeneration density and regeneration richness in the forest. Overall, all the above five site variables have a collective influence on the natural regeneration pattern in the studied forest. These findings have implications for natural resource management, especially in selecting suitable silvicultural systems under protected area management in the tropical forest where enhanced tree cover is needed. This study investigated few soil properties. Still, there is a need to examine the influence of some other soil chemical properties (e.g., soil nutrients) on regeneration. Other factors such as undergrowth, litter layer, and anthropogenic disturbances were also not measured, but for a better understanding of the regeneration pattern, further research is required on them and as well as on individual tree species responses.

\section{REFERENCES}

Alamgir, M. \& Al-Amin, M. (2007). Regeneration status in a proposed biodiversity conservation area of Bangladesh. Proceedings of the Pakistan Academy of Sciences, 44(3): 165-172.

Ara, S.H., Limon, M.H. \& Kibria, M.G. (2021). Distributional pattern of tree species in response to soil variables in a semi natural tropical forest of Bangladesh. Journal of Forest and Environmental Science, 37(1): 14-24.

Arshad, M.A., Lowery, B. \& Grossman, B. (1997). Physical tests for monitoring soil quality. Methods for Assessing Soil Quality, 49: 123-141.

Beckage, B. \& Clark, J.S. (2003). Seedling survival and growth of three forest tree species: the role of spatial heterogeneity. Ecology, 84(7): 1849-1861.

Bhattarai, K.R. \& Vetaas, O.R. (2006). Can Rapoport's rule explain tree species richness along the Himalayan elevation gradient, Nepal?. Diversity and Distributions, 12(4): 373-378.

Blake, G.R. \& Hartge, K.H. (1986). Bulk Density. In Klute, A. (ed.) Methods of Soil Analysis, part 1, Wiley \& Sons. pp. 363-375.

Bose, A.K., Weiskittel, A., Wagner, R.G. \& Kuehne, C. (2016). Assessing the factors influencing natural regeneration patterns in the diverse, multi-cohort, and managed forests of Maine, USA. Journal of Vegetation Science, 27(6): 1140-1150.

Brandon, K. (2014). Ecosystem services from tropical forests: review of current science. Center for Global Development Working Paper, (380).
Chazdon, R.L. (2003). Tropical forest recovery: legacies of human impact and natural disturbances. Perspectives in Plant Ecology, Evolution and Systematics, 6(1-2): 51-71.

Choudhury, B.I., Khan, K.L. \& Das, A.K. (2014) Seedling dynamics of the critically endangered tree legume Gymnocladus assamicus in Northest India. Tropical Ecology 55(3): 375-384.

Corlett, R.T. \& Primack, R.B. (2011). Tropical rain forests: an ecological and biogeographical comparison. John Wiley \& Sons.

Donato, D.C., Kauffman, J.B., Murdiyarso, D., Kurnianto, S., Stidham, M., \& Kanninen, M. (2011). Mangroves among the most carbon-rich forests in the tropics. Nature Geoscience, 4(5): 293-297.

Dutta, S., Hossain, M.K., Hossain, M.A. \& Chowdhury, P. (2015). Exotic plants and their usage by local communities in the Sitakunda botanical garden and eco-Park, Chittagong, Bangladesh. Forest Research, 4(136): 2.

Enoki, T. \& Abe, A. (2004). Saplings distribution in relation to topography and canopy openness in an evergreen broad-leaved forest. Plant Ecology, 173(2): 283-291.

FAO. 2015. State of the world's forests 2015. Rome, Food and Agriculture Organization of the United Nations.

Haider, M.R., Alam, S. \& Mohiuddin, M. (2017). Regeneration potentials of native tree species in three natural forests of Sylhet, Bangladesh. Journal of Biodiversity Conservation and Bioresource Management, 3(2): 1-10.

Hansen, M.C., Potapov, P.V., Moore, R., Hancher, M., Turubanova, S.A., Tyukavina, A., Thau, D., Stehman, S.V., Goetz, S.J., Loveland, T.R., Kommareddy, A., Egorov, A., Chini, L., Justice C.O. \& Townshend, J. (2013). High-resolution global maps of 21st-century forest cover change. Science, 342(6160): 850-853.

Hartshorn, G.S. (1995). Ecological basis for sustainable development in tropical forests. Annual Review of Ecology and Systematics, 26(1): 155-175.

Hossain, M.K. (2001). Overview of the forest biodiversity in Bangladesh in Assessment, Conservation and Sustainable Use of Forest Biodiversity. Secretariat of the Convention on Biological Diversity. Montreal. (CBD Technical Series no. 3)

Hossain, M.K., Rahman, M.L., Hoque, A.R. \& Alam, M. 
K. (2004). Comparative regeneration status in a natural forest and enrichment plantations of Chittagong (south) forest division, Bangladesh. Journal of Forestry Research, 15(4): 255-260.

Hossain, M.K. (2015). Silviculture of plantation trees of Bangladesh. Arannayk Foundation, Dhaka, Bangladesh, 361.

Hossen, S. \& Hossain, M.K. (2018). Conservation status of tree species in Himchari National Park of Cox's Bazar, Bangladesh. Journal of Biodiversity Conservation and Bioresource Management, 4(2): 1-10.

Ifo, S.A., Moutsambote, J.M., Koubouana, F., Yoka, J., Ndzai, S.F., Bouetou-Kadilamio, L.N.O., Mampouya, H., Jourdain, C., Bocko, Y., Mantota, A.B., Mbemba, M., Mouanga-Sokath, D., Odende, R., Mondzali, L.R., Wenina, Y.E.M., Ouissika, B.C. \& Mbemba, M. (2016). Tree species diversity, richness, and similarity in intact and degraded forest in the tropical rainforest of the Congo Basin: case of the forest of Likouala in the Republic of Congo. International Journal of Forestry Research, 2016: 1-12.

Joshi, H. \& Ghose, M. (2003). Forest structure and species distribution along soil salinity and $\mathrm{pH}$ gradient in mangrove swamps of the Sundarbans. Tropical Ecology, 44(2): 195-204.

Khaine, I., Woo, S.Y., Kwak, M., Lee, S.H., Je, S.M., You, H., ... \& Park, J.H. (2018). Factors affecting natural regeneration of tropical forests across a precipitation gradient in Myanmar. Forests, 9(3): 143.

Khurana, E.K.T.A. \& Singh, J.S. (2001). Ecology of seed and seedling growth for conservation and restoration of tropical dry forest: a review. Environmental Conservation, 28(1): 39-52.

Lee, S.Y., Primavera, J.H., Dahdouh-Guebas, F., McKee, K., Bosire, J.O., Cannicci, S., ... \& Record, S. (2014). Ecological role and services of tropical mangrove ecosystems: a reassessment. Global Ecology and Biogeography, 23(7): 726-743.

Lončarić, Z., Karalić, K., Popović, B., Rastija, D. \& Vukobratović, M. (2008). Total and plant available micronutrients in acidic and calcareous soils in Croatia. Cereal Research Communications, 36: 331-334.

Londo, A.J., Kushla, J.D. \& Carter, R.C. (2006). Soil pH and tree species suitability in the south. Southern Regional Extension Forestry, 2: 1-5.
MEA (2005). Ecosystems and human well-being: current state and trends. The millennium ecosystem assessment series xxi. Island Press, Washington, DC p 47.

Motaleb, M.A. \& Hossain, M.K. (2007). Studies on natural regeneration of a semi-evergreen forest of Chittagong (South) Forest Division. Bangladesh. Journal Forestry Environment, 5: 95-101.

Malik, Z.A. \& Bhatt, A.B. (2016). Regeneration status of tree species and survival of their seedlings in Kedarnath Wildlife Sanctuary and its adjoining areas in Western Himalaya, India. Tropical Ecology, 57(4): 677-690.

Modrý, M., Hubený, D. \& Rejšek, K. (2004). Differential response of naturally regenerated European shade tolerant tree species to soil type and light availability. Forest Ecology and Management, 188(1-3): 185-195.

Mukul, S.A., Arfin-Khan, M.A.S. \& Uddin, M.B (2021). Invasive alien species of Bangladesh. Invasive Alien Species: Observations and Issues from Around the World, 2: 1-15.

Nesa, M.L., Karim, S.S., Api, K., Sarker, M.M.R., Islam, M.M., Kabir, A., Sarker, M.K., Nahar, K., Asadujjaman, M.\& Munir, M.S. (2018). Screening of Baccaurea ramiflora (Lour.) extracts for cytotoxic, analgesic, anti-inflammatory, neuropharmacological and antidiarrheal activities. BMC Complementary and Alternative Medicine, 18(1): $1-9$.

Nicotra, A.B., Chazdon, R. L. \& Iriarte, S.V. (1999). Spatial heterogeneity of light and woody seedling regeneration in tropical wet forests. Ecology, 80(6): 1908-1926.

Offord, C. A., Meagher, P. F. \& Zimmer, H. C. (2014) Growing up or growing out? How soil $\mathrm{pH}$ and light affect seedling growth of a relictual rainforest tree. AoB Plants, 6: plu011.

Olson, M.G. \& Wagner, R.G. (2011). Factors affecting species richness of tree regeneration in mixed-wood stands of central Maine. Journal of Vegetation Science, 22(2): 303-311.

Pearson, T.R.H., Brown, S.L. \& Birdsey, R.A (2007). Measurement guidelines for the sequestration of forest carbon (Vol 18). USA: US Department of Agriculture, Forest Service, Northern Research Station. 
Piiroinen, T., Nyeko, P. \& Roininen, H. (2014). Canopy openness in gaps determines the influence of herbaceous climbers and insect folivory on the survival of a tropical pioneer tree, Neoboutonia macrocalyx Pax. African Journal of Ecology, 52(1): 41-49.

Rahman, M.L., Hossain, M.K. \& Karim, Q.M.N. (2000). Diversity and composition of tree species in Chunati Wildlife Sanctuary of Chittagong Forest Division, Bangladesh. Chittagong University Journal of Science, 24(1): 89-98.

Rahman, M.H., Khan, M.A.S.A., Roy, B. \& Fardusi, M.J. (2011). Assessment of natural regeneration status and diversity of tree species in the biodiversity conservation areas of Northeastern Bangladesh. Journal of Forestry Research, 22(4): 551-559.

Rahman, M.R., Hossain, M.K. \& Hossain, M.A. (2019). Diversity and composition of tree species in Madhupur National Park, Tangail, Bangladesh. Journal of Forest and Environmental Science, $35(3), 159-172$.

Rastogi, S., Kulshreshtha, D.K. \& Rawat, A.K.S. (2006). Streblus asper Lour. (Shakhotaka): a review of its chemical, pharmacological and ethnomedicinal properties. Evidence-Based Complementary and Alternative Medicine, 3(2): 217-222.

Redowan, M., Akter, S. \& Islam, N. (2014). Analysis of forest cover change at Khadimnagar National Park, Sylhet, Bangladesh, using Landsat TM and GIS data. Journal of Forestry Research, 25(2): 393-400.
Reza, A.A. \& Hasan, M.K. (2019). Forest biodiversity and deforestation in Bangladesh: the latest update. In Forest Degradation Around the World. IntechOpen.

Sobuj, N.A. \& Rahman, M. (2011). Assessment of plant diversity in Khadimnagar National Park of Bangladesh. International Journal of Environmental Sciences, 2(1): 79.

Tinya, F., Márialigeti, S., Bidló, A. \& Ódor, P. (2019). Environmental drivers of the forest regeneration in temperate mixed forests. Forest Ecology and Management, 433: 720-728.

Uddin, M.S., van Steveninck, E.D.R., Stuip, M. \& Shah, M.A.R. (2013). Economic valuation of provisioning and cultural services of a protected mangrove ecosystem: a case study on Sundarbans Reserve Forest, Bangladesh. Ecosystem Services, 5: 88-93.

UNEP (2014) In: Bochove J, Sullivan E, Nakamura T (eds) The importance of mangroves to people: a call to action. United Nations Environment Programme World Conservation Monitoring Centre, Cambridge, p 128.

Zegeye, H., Teketay, D. \& Kelbessa, E. (2011). Diversity and regeneration status of woody species in Tara Gedam and Abebaye forests, northwestern Ethiopia. Journal of Forestry Research, 22(3): 315328. 